Ethiopian Journal of Environmental Studies \& Management 7(6): 619 - 627, 2014.

ISSN:1998-0507

doi: http://dx.doi.org/10.4314/ejesm.v7i6.4

Submitted: June 24, 2014

Accepted: October 02, 2014

\title{
DETERMINATION OF LEVELS OF SOME INORGANIC GASEOUS CONTAMINANTS IN WARRI AND EFFURUN ENVIRONS IN DELTA STATE, NIGERIA
}

\author{
ONWUKEME, V.I. ${ }^{1}$ AND *ETIENAJIRHEVWE, O.F. 2 \\ ${ }^{1}$ Deparment of Pure and Industrial Chemistry, Nnamdi Azikiwe University, Awka, Anambra \\ State, Nigeria \\ ${ }^{2}$ Department of Science Laboratory Technology, Delta State Polytechnic, Otefe, Oghara, \\ Nigeria
}

\begin{abstract}
Eighteen air samples were collected from six locations in Effurun (Effurun Roundabout, Warri Refinery, Effurun Market) and in Warri (Enerhen Junction, NPA and Ogunu) environs and were analysed for Sulphur Dioxide $\left(\mathrm{SO}_{2}\right)$, Nitrogen Dioxide $\left(\mathrm{NO}_{2}\right)$ and Ozone $\left(\mathrm{O}_{3}\right)$. After various treatment of samples, $\mathrm{SO}_{2}, \mathrm{NO}_{2}, \mathrm{O}_{3}$ where determined with Spectrophotometer (Perkin Elmer Lambada $E=301)$. Mean concentrations of SO2; $161 \pm 0.00 \mathrm{ug} / \mathrm{m}^{3}, 67 \pm 0.00 \mathrm{ug} / \mathrm{m}^{3}$, $158 \pm 0.00 \mathrm{ug} / \mathrm{m}^{3}, 207 \pm 1.58 \mathrm{ug} / \mathrm{m}^{3}, 74 \pm 0.00 \mathrm{ug} / \mathrm{m}^{3}$ and $39 \pm 0.00 \mathrm{ug} / \mathrm{m}^{3}$ were obtained for the six sampling locations respectively; $\mathrm{NO}_{2} ; 138 \pm 1.58 \mathrm{ug} / \mathrm{m}^{3}, 123 \pm 0.00 \mathrm{ug} / \mathrm{m}^{3}, 141 \pm 0.00 \mathrm{ug} / \mathrm{m}^{3}$, $241 \pm 1.58 \mathrm{ug} / \mathrm{m}^{3}, 52 \pm 1.58 \mathrm{ug} / \mathrm{m}^{3}$ and $41 \pm 1.58 \mathrm{ug} / \mathrm{m}^{3}$ respectively for the six locations, and $\mathrm{O}_{3}$; $8.34 \pm 0.0158 \mathrm{ug} / \mathrm{m}^{3}, 8.06 \pm 0.0158 \mathrm{ug} / \mathrm{m}^{3}, 8.33 \pm 0.00 \mathrm{ug} / \mathrm{m}^{3}, 8.21 \pm 0.071 \mathrm{ug} / \mathrm{m}^{3}, 8.13 \pm 0.00 \mathrm{ug} / \mathrm{m}^{3}$ and $8.03 \pm 0.07 \mathrm{ug} / \mathrm{m}^{3}$ respectively for the six locations. All the studied locations were found to be contaminated/slightly polluted by these gaseous components. This calls for measures to mitigate these due to the possible health implications of the pollutants.
\end{abstract}

Key Words: Warri, Effurun, Passive method, Gaseous pollution.

\section{Introduction}

Elevated level of gaseous contaminants has been observed in air in the vicinity of certain industries like refineries, ports, and near busy roads and within urban areas in general (Ekeayanwu, 2006) The measured levels of these contaminants serve as an index of air pollution (Nguyen, 1997, Khandekar et al., 1980). Although, some elements such as $\mathrm{Zn}, \mathrm{Cu}, \mathrm{Mn}$, and $\mathrm{Fe}$ are essential micronutrients, they are toxic if exposure levels are sufficiently high (Prasad, 1988).

The presence of elemental concentration in the atmosphere of one or more contaminants of combination thereof in such quantities of such duration may cause injury to human health, plant or animal life or properties (materials) or may reasonably interfere with the comfortable enjoyment of life or properties or the conduct of business (Canter, 1996). Analysis of air quality in certain locations shows presence of numerous substances in trace amounts some of which could be explained to emanate from either natural or anthropogenic sources. Other substance could be formed indirectly from chemical process in the atmosphere. The combination of a source to the atmosphere varies according to its emission characteristics and the emitted substance. Concerns about the air we breathe has

*Corresponding Author: Etienajirhevwe, I.F.

Email: omonigho4jesus@yahoo.com 
probably been around as long as mankind from the moment fire was invented, the pollution of our atmospheric air became a problem (Brimblecombe, 1987) and it has been a problem ever since. Concerns have occurred periodically throughout history, and are well documented (Ashby and Anderson, 1981, Brimblecombe, 1987, NSCA, 2000) Despite the essentials ingredient of air to life, its qualities has been historically variable and frequently to the detriments of human health. Now, however, a growing body of research has found that certain substances may affect human health at concentrations that are greater. This concern has heightened public anxiety to the importance of improving and managing air quality. It is paramount that a resource as important as air quality is protected and managed for future generations. (Department of the Environment, (DOE) 1993)

Little positive attention has been paid to air pollution control despite the efforts of many individuals including pamphleteer, John Evelyn, who in 1661 published one of the first written account on air pollution entitled; "fumifugium of the Air and Smoke of London Dissipated". Despite this early recognition of the problem, little attempt has been made to control air pollution until the late $19^{\text {th }}$ and early $20^{\text {th }}$ centuries, even though many countries were gripped by the industrial revolution. The revolution was based on coal as the energy source, and thereby brought worsening level of air pollution (Harrop, 2002).

Ekeayanwu (2006) carried out studies on the pollution of the Warri environment where various concentrations of gaseous pollutants were recorded; despite this nothing reasonable has been done to control the air pollution we breathe.

Analysis of air pollution in some countries has been found to be increasing rapidly while some tend to be declining
(Belfast City Council Environmental, 2003) as monitored air quality data showed that the level of air pollution breached the recommended by the European Commission.

Harrop and Nixon, 1999 has recorded elevated level of sulphur dioxide in Northern Ireland and concluded that it could be due to sulphur emission from a lagoon close to the monitoring site.

The work is aimed at the determination of gaseous contaminants of the atmosphere in Effurum and Warri in Delta State, Nigeria, their effects and possibly proffers ways of reducing such effects.

\section{Materials and Methods \\ Study Area}

Effurun and Warri are urban areas located in Uvwie and Warri South local Government area respectively in Delta State, Nigeria. The study area is bounded by Latitude $5^{\circ} 15^{\prime} \mathrm{N}$ and $6^{\circ} \mathrm{N}$ and Longitude $5^{\circ} 40^{\prime} \mathrm{E}$ and $6^{\circ} 25^{\prime} \mathrm{E}$. They host different companies Refineries, Gas Company, Air and Sea Ports, fuelling stations, etc. and other automobile activities.

\section{Sample Collection and Preparation}

The study was conducted at Effurun and Warri areas of Delta state using passive method. Three sites were studied in Effrum and three in Warri, making a total of six. The samples were collected at the six sites within the studied area. The sites were carefully chosen based on accessibility, freedom from any obstacle to free flow of air in the vicinity and security of the samplers. The sites were chosen also to reflect activities in the area. Samplings at the various sites were carried out during the dry season only. A total of eighteen (18) air samples were collected from six locations in Effurun (Effurun Roundabout, Warri Refinery, Effurun Market) and in Warri (Enerhen Junction, NPA and Ogunu) environs for a period of two weeks (fourteen days) 


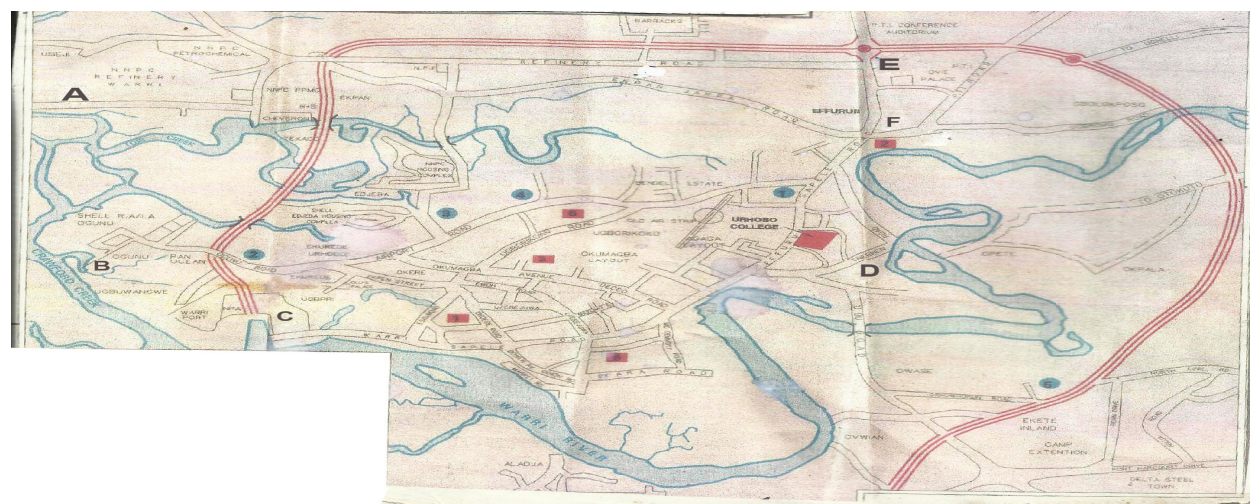

Key: A - Warri Refinery, B - Ogunu, C - Nigeria Port Authority (NPA), D - Enerhen Junction, E - Effurun Roundabout and F - Effurun Market

Figure 1: Map of study area showing samples collection sites

\section{Ozone $\left(\mathrm{O}_{3}\right)$}

Adsorbent paper and a glass tubes opened at one end were used as sampler. The adsorbent papers were treated with an ethene solution for a period of thirty minutes and were allowed to dry in an air tight preparation room. The treated adsorbent paper was inserted into the glass tube, capped and transported to the sampling sites. At the sampling site, glass tube was mounted on a pole at the height of 2.0 meters from ground to allow free flow of air into the treated paper for adsorption of ozone component. This procedure was carried out for all six sites studied and samplers were allowed to stay for a period of fourteen days with proper monitoring to prevent any form of obstacle

\section{Sulphur Dioxide $\left(\mathrm{SO}_{2}\right)$}

The samplers used for the preparation for $\mathrm{SO}_{2}$ determination was a glass tube opened at one end and adsorbent paper treated with a mixture of sodium trioxocarbonate (IV) (15\%), Glycerine (5\%), and distilled water $(80 \%)$ prepared in a volumetric flask (Pyrex) , dried and kept in an air tight container and was transported to the sampling sites and inserted into one opened end glass tube and was subsequently mounted on a pole at a height of 2.0 meters from the ground in such a way to allow free flow of air ,to adsorb $\mathrm{SO}_{2}$ components. This was done for all six locations and sampling was for a period of fourteen days with proper monitoring to prevent any form of obstacle.

\section{Nitrogen Dioxide $\left(\mathrm{NO}_{2}\right)$}

The collection of $\mathrm{NO}_{2}$ components was carried out with the aid of a glass tube opened at one end and an adsorbent paper treated with a mixture of triethylamine (TEA) (25\%), ethylene glycol (5\%) and distilled water $(70 \%)$ prepared in a $100 \mathrm{ml}$ volumetric flask. The adsorbent paper was allowed to absorb the mixture for a period of thirty (30) minutes and was dried in vacuum oven for a period of ten (10) minutes. This was kept in an air tight container, sealed and transported to the sampling sites. The treated paper was inserted into the glass tube and was mounted on a pole at the height of 2.0 meter from ground to allow free flow of air into it. This procedure was carried out for ten six sites studied and sampling were allowed for a periods of fourteen days with regular monitoring.

\section{Harvesting of Samplers}

All the samplers mounted were harvested after a period of fourteen (14) days. The glass tubes which were initially opened for in flow of air were then closed with special caps to avoid any form of contamination and desorption. The samples were placed into tightly closed special plastic bags and were 
kept in a refrigerator at a controlled temperature until they were processed. All the samples harvested were treated with extreme carefulness to avoid any form of contamination and desorption

\section{Sample Analysis Ozone $\left(\mathrm{O}_{3}\right)$}

The absorbent paper harvested for the determination of ozone was cut into pieces in an uncontaminated preparatory room to avoid further adsorption of contaminants. These were extracted using deionized water over low heat using a magnetic stirrer, cooled and filtered into a conical flask. $40 \mathrm{ml}$ of the extracts were measured into a conical flask and were filled with an indigo ozone reagent ("Accu vac Ampul") and were subsequently analysed for ozone concentration with the aid of a UV/VIS spectrophotometer (Perkin Elmer Lambada $\mathrm{E}=301$ ) at a wavelength of 450nm. Blank determination was also carried out in the same manner (HACH, 2002).

\section{Sulphur Dioxide, $\left(\mathrm{SO}_{2}\right)$}

The adsorbent paper harvested for the determination of $\mathrm{SO}_{2}$ was cut into pieces in an uncontaminated preparatory room and were digested and extracted by bubbling them in a solution of $0.05 \%$ solution of hydrogen peroxide $\left(\mathrm{H}_{2} \mathrm{O}_{2}\right)$ in distilled water with the aid of a magnetic stirrer for a period of thirty (30) minutes. $10 \mathrm{ml}$ of the extracts were measured into a clean cell and one content of a "Sulfaver 4" reagent pillow was added to the content (to ensure colour development of $\mathrm{SO}_{2}$ in the samples) and was thoroughly swirled to ensure proper mixing. The solution were subsequently analysed for $\mathrm{SO}_{2}$ concentration with the aid of a UV/VIS Spectrophotometer (Perkin Elmer Lambada E $=301$ ) with their concentration recorded at a wavelength of $680 \mathrm{~nm}$. Blank determination was also carried out in the same manner (HACH, 2002)

\section{Nitrogen Dioxide $\left(\mathrm{NO}_{2}\right)$}

Harvested adsorbent paper for the determination of $\mathrm{NO}_{2}$ was cut into pieces in an uncontaminated preparation room. Colourimetric method, involving direct absorbance measurement of sample and treated standard at a wavelength of $550 \mathrm{~nm}$ was used. The adsorber paper was digested with adsorbing solution of $\mathrm{N}$-(1-Napthl) ethylenediamine dihydrochloride (Saltzman, 1954, ASTM, 1977) for a period of thirty (30) minutes using a magnetic stirrer. This was then filtered into a volumetric flask, $25 \mathrm{~mL}$ of which was measured into a measuring cylinder, "Nitraver 6" reagent powder pillow was added to ensure $\mathrm{NO}_{2}$ development, stoppered and homogenized and subsequently analysed with the aid of uv/vis spectrophotometer at a wavelength of 550nm (HACH 2002) Blank determination was also carried out in the same manner.

\section{Results and Discussion}

Table 1 and Figures1-3, present the result of total extractable inorganic gases in Warri and Effurun environs in comparison with air quality guidelines.

Table 1: Results for $\mathrm{SO}_{2}, \mathrm{NO}_{2}$ and $\mathrm{O}_{3}$

\begin{tabular}{lllc}
\hline Locations & \multicolumn{1}{c}{$\mathrm{SO}_{2} \mathrm{ug} / \mathrm{m}^{3}$} & $\mathrm{NO}_{2} \mathrm{ug} / \mathrm{m}^{3}$ & $\mathrm{O}_{3} \mathrm{ug} / \mathrm{m}^{3}$ \\
\hline Effurum Roundabout $(\mathrm{n}=3)$. & $161 \pm 0.00$ & $138 \pm 1.58$ & $8.34 \pm 0.0155$ \\
Warri Refinery $(\mathrm{n}=3)$ & $67 \pm 0.00$ & $123 \pm 0.00$ & $8.06 \pm 0.958$ \\
Effurun market $(\mathrm{n}=3)$ & $158 \pm 0.00$ & $141 \pm 0.00$ & $8.33 \pm 0.000$ \\
Enerhen junction (n=3 & $207 \pm 1.58$ & $241 \pm 1.58$ & $8.21 \pm 0.071$ \\
N.P.A (n=3) & $74 \pm 0.00$ & $52 \pm 1.58$ & $8.13 \pm 0.000$ \\
Ogunu (n=3) & $39 \pm 0.00$ & $41 \pm 1.58$ & $8.03 \pm 0.071$ \\
OSHA (2002) & 130 & $\mathrm{~N} / \mathrm{A}$ & 200 \\
FMEnv (2000) & $100-150$ & 150 & $\mathrm{~N} / \mathrm{A}$ \\
WHO (2000) & $125 /$ day & 200 & 120 \\
\hline
\end{tabular}

SD: standard deviation 


\section{Sulphur Dioxide $\left(\mathrm{SO}_{2}\right)$}

Sulphur dioxide concentration obtained from the ambient air in Warri and Effurun environ as shown above ranged from 39 $207 \mathrm{ug} / \mathrm{m}^{3}$ with Enerhen junction recording the highest concentration value of $207 \mathrm{ug} / \mathrm{m}^{3}$ while Ogunu recorded the lowest concentration value $39 \mathrm{ug} / \mathrm{m}^{3} . \quad \mathrm{SO}_{2}$ concentration of $161 \mathrm{ug} / \mathrm{m}^{3}, \quad 67 \mathrm{ug} / \mathrm{m}^{3}$, $158 \mathrm{ug} / \mathrm{m}^{3}$ and $74 \mathrm{ug} / \mathrm{m}^{3}$ were recorded at Effurun Roundabout, Warri Refinery, Effurun market, and NPA respectively. These results corroborate Ekeayanwu 2006, who recorded concentrations of $27-182 \mathrm{ug} / \mathrm{m}^{3}$ in the Warri environs. Research also made it clear that high concentrations of 509, and $326 \mathrm{ug} / \mathrm{m}^{3}$ were recorded in $1989 / 90$ and 1990/91 at Belfast respectively (Belfast City Council, 2003). Various concentrations obtained in this present study could be attributed to the nature of activities being carried out in the environment. Comparison between $\mathrm{SO}_{2}$ concentrations from Warri and Effurun environs with standards limits for ambient air showed that Warri Refinery, NPA and Ogunu studied locations with values of 67,74 and $39 \mathrm{ug} / \mathrm{m}^{3}$ were all in safe limits as provided by OSHA, Federal Ministry of Environment (FMEnv) in Nigeria and World Health Organization (WHO) with maximum permission values of 130,100 150 , and $124 \mathrm{ug} / \mathrm{m}^{3}$ respectively (Table 1 ). Based on these values provided by the monitoring body, these locations could be said to be unpolluted with $\mathrm{SO}_{2}$ or slightly polluted. Effurun Roundabout, Effurun market and Enerhen junction with $\mathrm{SO}_{2}$ concentration values of 161, 158 and $207 \mathrm{ug} / \mathrm{m}^{3}$ respectively were above the critical value for quality air provided by the OSHA, FMEnv and WHO which showed that these three locations are polluted with $\mathrm{SO}_{2}$.

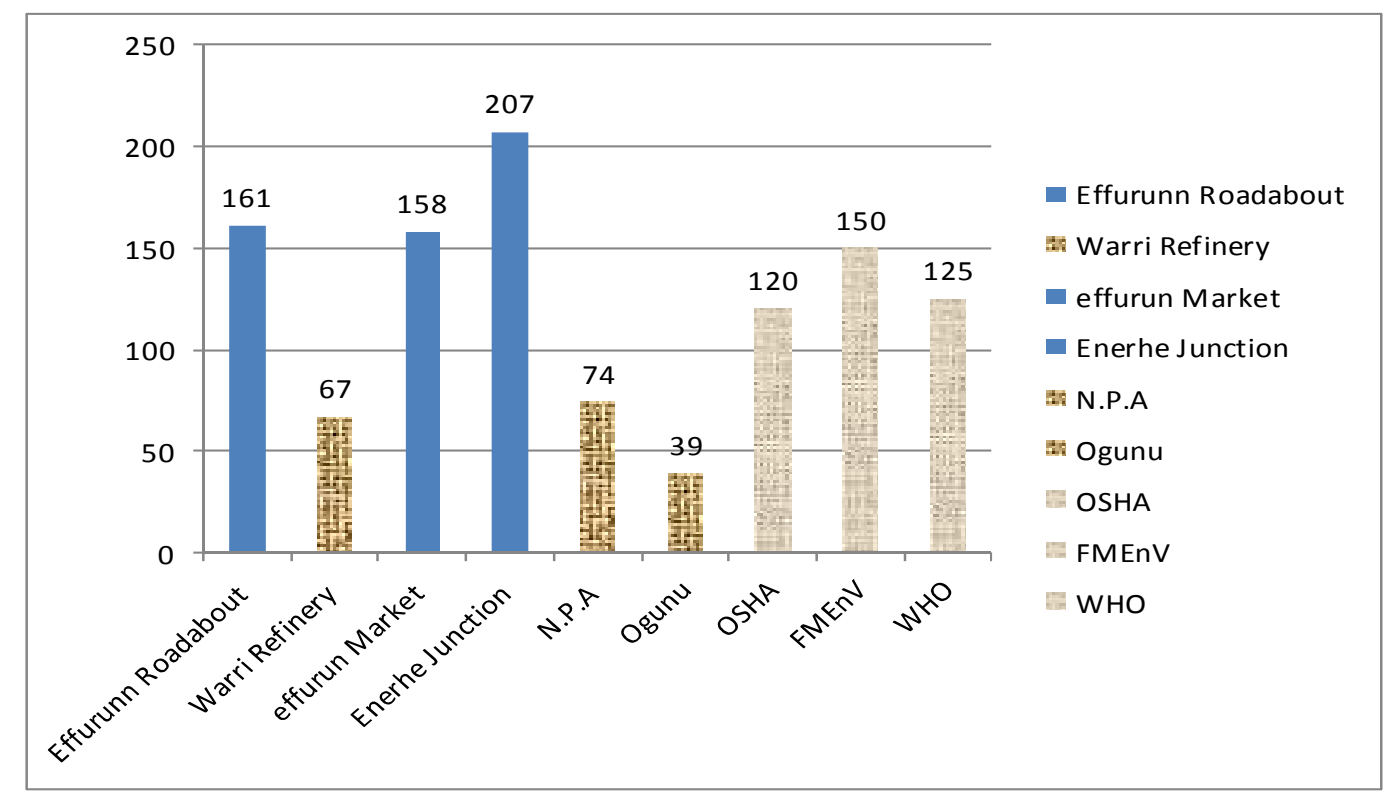

Figure 2: $\mathrm{SO}_{2}$ concentrations $\left(\mathrm{ug} / \mathrm{m}^{3}\right)$ in Warri and Effurun in comparison with OSHA, FMEnv and $\mathrm{WHO}$

It is worthy to note that exposure to concentration values above the permissible limit for ambient air would result to health effects such as respiratory irritant (Environment Agency, (2000)), stimulation of nerves in the lining of the nose, throat and 
airways of the lungs. It has also been reported that people suffering from asthma may be susceptible to the adverse effect of $\mathrm{SO}_{2}$. Though some locations are polluted and some not or slightly polluted, it should be noted that exposure to $\mathrm{SO}_{2}$ concentration of 20ppm causes eye irritation and coughing in healthy adults, 15ppm for 1 hour decreases mucoduary activity, 5ppm causes throat irritation in healthy adults at rest, $0.19 \mathrm{ppm}$ for 24hours leads to aggravation of chronic respiratory disease in adults while $0.07 \mathrm{ppm}$ for animal exposure lead to aggravation in children (Harrop, 2002). It should also be noted that one of the primary pollutant of principal concern is the formation of acid rain is $\mathrm{SO}_{2}$ which can react with oxides of Nitrogen and oxidized to form $\mathrm{H}_{2} \mathrm{SO}_{4}$ either in the atmosphere or after deposition.

\section{Nitrogen Dioxide}

The results of nitrogen dioxide are in the range of $41-241 \mathrm{ug} / \mathrm{m}^{3}$ (Table 1) with Enerhen junction recording the highest concentration value of $241 \mathrm{ug} / \mathrm{m}^{3}$ while the lowest concentration value of $41 \mathrm{ug} / \mathrm{m}^{3}$ was recorded at Ogunu studied location. Effurun Roundabout, Warri Refinery, Effurun Market, NPA recorded concentration value of 138, 123, 141 and $52 \mathrm{ug} / \mathrm{m}^{3}$ respectively
(Table 1) These values corroborates 28 $128 \mathrm{ug} / \mathrm{m}^{3}$ reported by Ekeayanwu 2006 in the Warri environs but present day results could be attributed to emission from motor vehicle, large scale industrial combustion process and other domestic and commercial activities around the studied locations. The mean concentration values of $\mathrm{NO}_{2}$ in comparison with ambient Air Quality Standards showed that Effurun Roundabout, Warri Refinery, Effurun Market, NPA and Ogunu studied locations with concentration values of $138,123,141,52$ and $41 \mathrm{ug} / \mathrm{m}^{3}$ respectively were in safe limit of the Ambient Air Quality Standard provide by FEMnv and WHO with maximum permissible values of 150 and $200 \mathrm{ug} / \mathrm{m}^{3}$. These values showed that these five studied location are only unpolluted as results obtained from the analysis are lower than the critical limit set by these regulatory bodies. Enerhen Junction studied location with $\mathrm{NO}_{2}$ concentration values of $241 \mathrm{ug} / \mathrm{m}^{3}$ fell above the critical permissible value of FEMnv and WHO of 150 and $200 \mathrm{ug} / \mathrm{m}^{3}$ respectively. Based on these values, it could be said that Enerhen Junction studied location was polluted with $\mathrm{NO}_{2}$ as its concentration fell above the critical value of FMEnv and WHO.

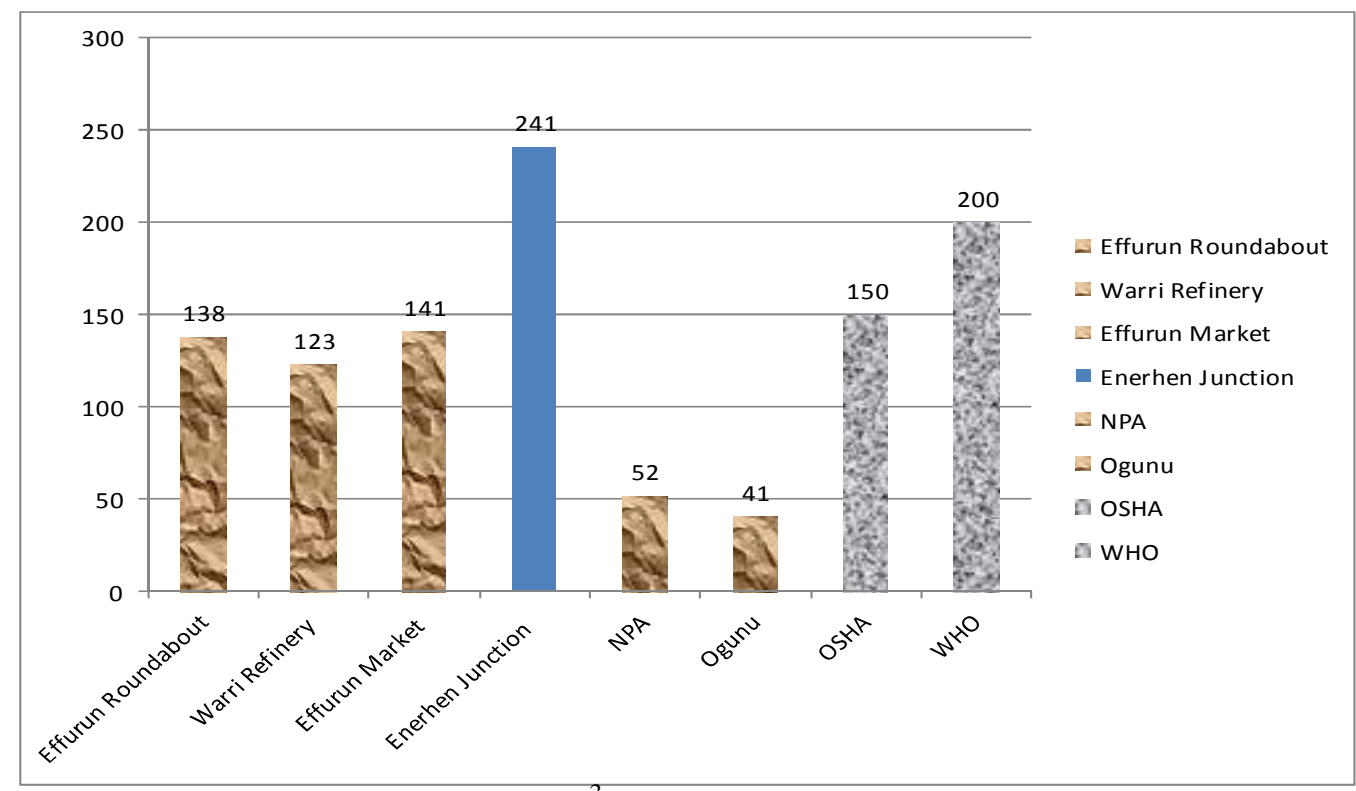

Figure 2: $\mathrm{NO}_{2}$ concentrations $\left(\mathrm{ug} / \mathrm{m}^{3}\right)$ in Warri and Effurun in comparison with OSHA and WHO 
It is worth noting that since there are traces of $\mathrm{NO}_{2}$ in all the studied locations with value higher or lower than those set up by the various regulatory bodies, over exposure to such concentration over a long period of time pose danger to human health. The effect of over exposure to concentration below or above the critical value could bring about reversible effect on lungs function and airway responsiveness and increase reactivity to natural allergens. $\mathrm{NO}_{2}$ exposure could also put children at an increased risk of respiratory infection and may lead to poorer lung function in after life. At relatively high concentration $\mathrm{NO}_{2}$ could cause acute inflammation of the pathways. Asthmatics are very sensitive to air with exposure to concentration of about $56 \mathrm{ug} / \mathrm{m}^{3}$ for thirty (30) minutes producing as small change in standard indices of lung function in nonasthmatics; exposure to about $1800 \mathrm{ug} / \mathrm{m}^{3}$ would be necessary to produce a similar response. The exposure response relationship for $\mathrm{NO}_{2}$ is erratic. Exposure to concentration of $560 \mathrm{ug} / \mathrm{m}^{3}$ may produce a response whilst exposure to double that may not; the response may not reappear and remain as concentration approach and exceed $1800 \mathrm{ug} / \mathrm{m}^{3}$ though the explanation for this is not clear (European Environment Agency, 2000a)

Ozone

The concentrations of ozone from our studied location range from $8.03-8.34 \mathrm{ug} / \mathrm{m}^{3}$ with Effurun Roundabout recording the highest concentration value $8.34 \mathrm{ug} / \mathrm{m}^{3}$ (Table 1). Warri Refinery, Effurun market, Enerhen junction and NPA recorded concentration values of $8.06,8.33,8.21$ and $8.13 \mathrm{ug} / \mathrm{m}^{3}$ respectively. A generally low concentration was obtained from all the studied location. Low concentration of $6.20-7.54 \mathrm{ug} / \mathrm{m}^{3}$ recorded by Ekeayanwu 2006 and the ones recorded in this present study, justifies the statement of Harrop 2002, that low concentration values of ozone from the various locations could be attributed to the presence of high motor vehicle because in areas with high motor vehicle, flow $\mathrm{O}_{3}$ concentration tend to be low as any $\mathrm{O}_{3}$ generated is utilized up in the conversion of $\mathrm{NO}$ to $\mathrm{NO}_{2}$. Comparison between the concentrations of Ozone obtained from the studied locations and the limit provided by OSHA and WHO for air quality showed that all the studied locations fell below the values set by these regulatory bodies. This showed that none of the studied area was polluted with ozone

The comparison of the concentration of these gaseous for the various locations with the standards given by the regulatory bodies is given in Figure 3.

Though low concentrations were detected, over exposure or long term exposure poses danger to human health, according to WHO, (1987), hourly concentration $200 \mathrm{ug} / \mathrm{m}^{3}$ can cause eye and nose irritation, chest discomfort, cough and headache; exposure to about six hours concentration of $160 \mathrm{ug} / \mathrm{m}^{3}$ have been shown to produce inflammation of the airway and change in standard indices of lung function. Short term exposure $\left(300-500 \mathrm{ug} / \mathrm{m}^{3}\right)$ of $\mathrm{O}_{3}$ may impair mechanical function of the lungs and many induce respiratory and related symptoms in sensitive individuals (those with asthma, emphysema, or reduced lung function) (Utah State Department for the Environment, 2000). 


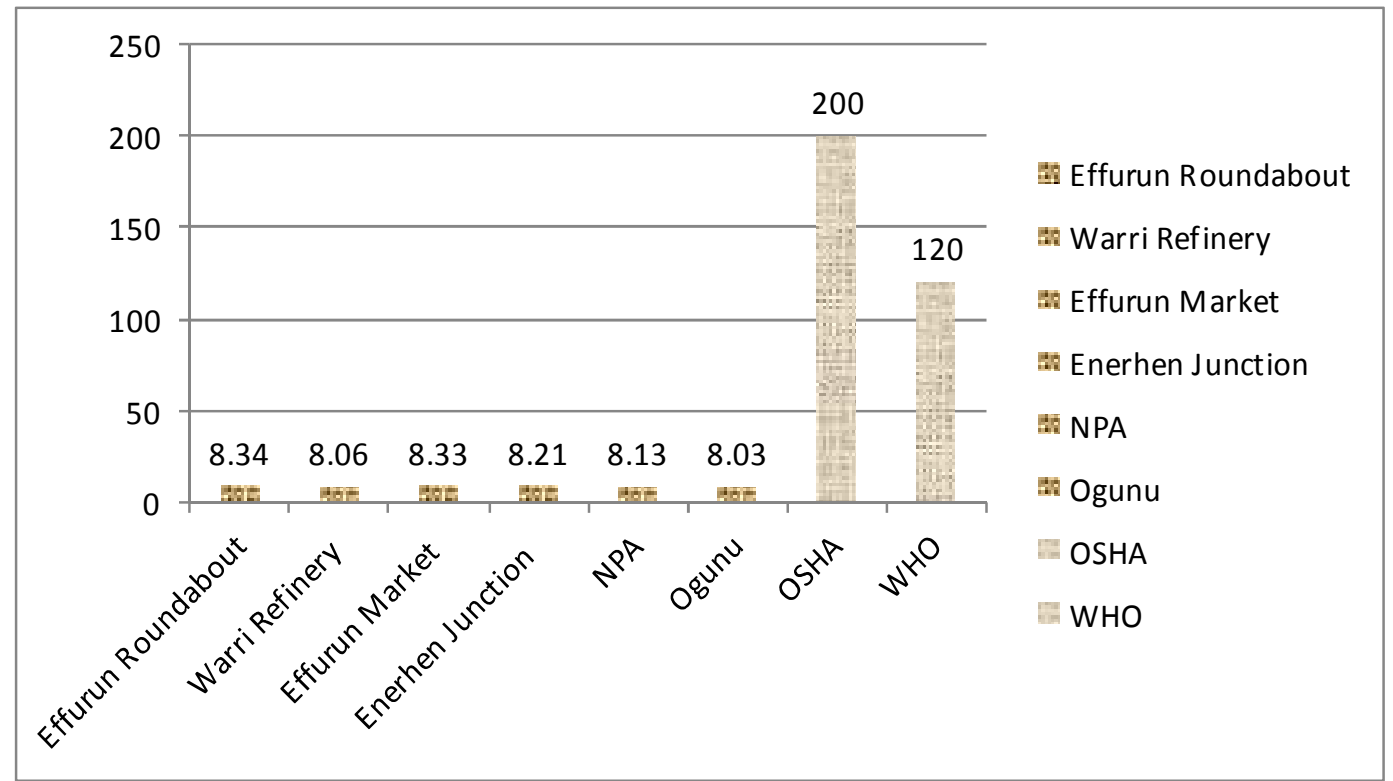

Figure 3: $\mathrm{O}_{3}$ Concentrations $\left(\mathrm{ug} / \mathrm{m}^{3}\right)$ in Warri and Effurun atmosphere in comparison with OSHA and $\mathrm{WHO}$

\section{Conclusion and Recommendation}

All the studied locations are found to be contaminated with sulphur dioxide, $\left(\mathrm{SO}_{2}\right)$, nitrogen dioxide $\left(\mathrm{NO}_{2}\right)$ and Ozone $\left(\mathrm{O}_{3}\right)$. Analytical results found some areas polluted while others contaminated or slightly polluted based on comparison of results of analysis with critical values (limits) set by various monitoring bodies such as Federal Ministry of Environment (FMEnv), Occupational Safety and Health Administration (OSHA) and World Health Organization (WHO). Amongst all studied locations, Enerhen junction was found to be the most polluted / contaminated though it was stated that Enrehen junction is the busiest of all studied area. Warri refinery and Ogunu was the least contaminated / polluted area and these two were the less busy studied area. Over exposure to polluted environment above the critical values set by FMEnv, OSHA and WHO for ambient air pose serious health problems. We must therefore, as an individual consider the consequences for our actions and work to improve air quality for future generation.

\section{Acknowledgement}

$\mathrm{Mr}$ Adeola Bamgboye of Lighthouse Petroleum Engineering Company Limited, Effurun, Delta State and Staff of Delta State Polytechnic, Otefe, Oghara are hereby appreciated for the use of their laboratory for chemical analysis.

\section{References}

Ashby, E. and Anderson, M. (1981). The Politics of Clean Air, Oxford University Press, Oxford.

ASTM (1977). Test Methods for Nitrogen Oxides (combined) content in the

atmosphere by the Geriess Sattzman reaction. Annual Book of ASTM Standards, 26: $783-787$.

ASTM (1988). Method D 3686-84: Standard Practices for Sampling Atmosphere to collect organic compounds vapour (activated charcoal tube adsorption method) Annual Book of ASTM Standards, 11(3): $234-240$. 
Belfast City Council Environmental Health Department, (2003). Belfast City Council - Personal Communication.

Brimblecombe, P. (1987). The Big Smoke A history of Air Pollution in London since Medieval Times, Routtledge, London.

Canter, L. (1996). Environmental Impact of Agricultural Production Activities, Lewis Publishers Inc, Chelsea, Michigan, 169 - 209.

Ekeayanwu, E.C. (2006). Pollution of the Warri Environment. HND final year project, Department of Industrial safety and Environmental Technology, Petroleum Training Institute, Effurun, Nigeria.

Federal Ministry of Environment (2000). Guidelines and Standards for Environmental pollution and control in Nigeria, Lagos.

HACH (2002). The HACH Handbook for portable Spectrophotmeter, DR 2400 Methods 8039, 8051 and 8331(2006).

Harrop, D.O. and NIxen, J.A. (1999). Environmental Assessment in Practice, Routledge, London.

Harrop D.O (2002). Air Quality Assessment and Management, A practical guide, Spon Press, London and New York.

Khandekar, R.N., Kelkar, D.N. and Vohra, K.G. (1980). Lead, cadmium, zincand iron in the atmosphere of greater bombay. Atmospheric Environment, 14: $457-461$.

Nguyen, T.N. (1997). Trace Element Analysis with application to Environmental Pollutant studies in
Vietnam, PhD thesis, Environmental Physics Group, Physics and Engineering Physics, Chalmers University of Technology and Goteborg University, Goteborg, Sweden.

National Society for Clean Air and Environmental Protection (NSCA) (2000). Pollution Handbook, Brighton.

Occupational Safety and Health Administration (2002). United State, Environmental Protection Agency, Occupational Health Standards.

Prasad, A.S. (1998). In Current Topics in Nutrition and Disease Vol 18: Essential and Toxic Trace Elements in Human Health and Disease, Alan R Liss Inc, New York.

Satzman, B.E. (1954). Colorimetric Micro determination of Nitrogen Dioxide in the Atmosphere, Analytical Chemistry, 26: $19-49$.

Utah State Department for the Environment (2000). Internet site: www.ut.us. Accessed July 2013.

World Health Organisation (1994). Updating and Revision of the Air Quality Guidelines for Europe - Inorganic Air Pollutants. EUR/ICP/EHAZ 9405/MT04, Regional Office for Europe, Copenhagen.

World Health Organisation European Centre for Environment and Health (1995). Concern for Environment and Health, Concerns for Europe's tomorrow.

World Health Organisation (2000).
Guidelines for Air Quality,
WHO/SDE/OEA/00.02, Geneva.

